\title{
Description of mature larvae and ecological notes on Gasteruption Latreille (Hymenoptera, Evanioidea, Gasteruptiidae) parasitizing hymenopterans nesting in reed galls
}

\author{
Petr Bogusch', Cornelis van Achterberg², Karel Šilhán', \\ Alena Astapenková', Petr Heneberg ${ }^{3}$
}

I Department of Biology, Faculty of Science, University of Hradec Králové, Rokitanského 62, CZ-500 03 Hradec Králové, Czech Republic 2 Department of Terrestrial Zoology, Naturalis Biodiversity Center, Pesthuislaan 7, 2333 BA Leiden, The Netherlands 3 Third Faculty of Medicine, Charles University, Ruská 87, CZ-100 00 Praha, Czech Republic

Corresponding author: Petr Bogusch (bogusch.petr@gmail.com)

Academic editor: M. Ohl | Received 13 May 2018 | Accepted 19 June 2018 | Published 27 August 2018

http://zoobank.org/D49D4029-A7DA-4631-960D-4B4D7F512B8D

Citation: Bogusch P, van Achterberg C, Šilhán K, Astapenková A, Heneberg P (2018) Description of mature larvae and ecological notes on Gasteruption Latreille (Hymenoptera, Evanioidea, Gasteruptiidae) parasitizing hymenopterans nesting in reed galls. Journal of Hymenoptera Research 65: 1-21. https://doi.org/10.3897/jhr.65.26645

\begin{abstract}
Wasps of the genus Gasteruption are predator-inquilines of bees nesting in cavities in wood, stems, galls, and vertical soil surfaces. During studies of hymenopterans associated with reed galls caused by flies of the genus Lipara we recorded three species. We provide the evidence that a rare European species Gasteruption phragmiticola is a specialized predator-inquiline of an equally rare wetland bee Hylaeus pectoralis. Gasteruption nigrescens is a predator-inquiline of bees of the family Megachilidae, using the common bee Hoplitis leucomelana as the main host. Gasteruption assectator is a less specialized predatorinquiline of multiple groups of bees. The first two species, G. phragmiticola and G. nigrescens, are usually present at well-preserved reed beds associated with meadows rich in flowering plants while $G$. assectator does not prefer any specific habitat. Mature larvae of Gasteruption typically have a dorsoventrally flattened body and lateral lobes, small head with only slightly sclerotized mouthparts and tridentate mandibles. The larvae of these three species differ only slightly from one another, at most by the sclerotization of the mouthparts, colour, and position of setae on the head capsule and the shape of the mandible. As previous descriptions are insufficient, we provide first detailed descriptions with figures.
\end{abstract}

Copyright Petr Bogusch et al. This is an open access article distributed under the terms of the Creative Commons Attribution License (CC BY 4.0), which permits unrestricted use, distribution, and reproduction in any medium, provided the original author and source are credited. 


\section{Keywords}

bees and wasps, Gasteruption, Hylaeus pectoralis, host records, larval description, Lipara, reed beds

\section{Introduction}

The genus Gasteruption Latreille, 1796, represents a relatively uniform group of parasitoid wasp-like hymenopterans, characterized by their slender body, thick hind tibiae and short to very long ovipositor of females (Kieffer 1912, Šedivý 1958, Wall 1994, van Achterberg and Talebi 2014). Around 500 species are known worldwide, of which 30 species have been recorded in Europe (van Achterberg and Talebi 2014). These insects are predator-inquilines in nests of solitary bees laying their eggs into the nests of species nesting usually in cavities in wood, stems, stalks, vertical walls, and also in galls (Schletterer 1885, Malyshev 1965, Wall 1994, Steffan-Dewenter and Leschke 2003, Saure 2006), and several individuals were also reared from fungi (Kula et al. 1999, Ševčík 2003). Larvae consume the host larva and feed on pollen and nectar provisions, several species leave the host larvae to grow up and consume them just before the end of their development. Although several authors have published data on host associations with predatory hymenopterans (Crabronidae and Vespidae) (Kieffer 1912, Wall 1994), all these observations have not been confirmed. Detailed bionomy of species of this genus is usually only poorly known: there are quite many records of floral and host associations published in monographs and also in short research articles but most of them are based only on observations of these parasitoids at localities (most is reviewed by Wall 1994). According to these studies (Malyshev 1965, Oehlke 1984, Wall 1994, Jennings and Austin 2004, van Achterberg and Talebi 2014), bees of the genus Hylaeus Fabricius, 1793 are supposed to be the hosts of most species while several are being connected also with smaller species of the family Megachilidae.

Very specific guild of bees and wasps make their nests in old cigar galls of the frit flies genus Lipara Meigen, 1830, on common reed (Phragmites australis). Astapenková et al. (2017) reviewed that 39 species use these specific cavities for their nesting, and around ten other species are commonly recorded ovipositing in their nests (parasitoids and nest cleptoparasites). Several species use exclusively or very preferably these galls for their nesting while Hylaeus pectoralis Foerster, 1871, is the typical example of specialist nesting exclusively in reed galls (see Bogusch et al. 2017). This small bee species has been commonly recorded to be a host of several Gasteruption species: Gasteruption assectator (Linnaeus, 1758) (Habermehl 1921, Crosskey 1951), Gasteruption erythrostomum (Dahlbom, 1831) by Malyshev (1965), Gasteruption freyi (Tournier, 1877) (Malyshev 1965, Oehlke 1984, Westrich 1989), Gasteruption jaculator (Linnaeus, 1758) (Malyshev 1965, Oehlke 1984), and Gasteruption phragmiticola Saure, 2006 (Saure 2006, Westrich 2008).

During studies of bees and wasps utilizing empty cigar galls on common reed, we recorded three species of the genus Gasteruption. The previously published descrip- 
tions of Gasteruption larvae include only two studies that described in part the larva of $G$. assectator-complex, with the Crosskey's (1951) description being very brief and Short's (1952) study containing very good drawings of the head of the mature larva of $G$. assectator but no description. Here, we aimed to synthetize the obtained information and, particularly, to elucidate the host specialization of commonly occurring Gasteruption assectator, locally common but relatively recently described Gasteruption phragmiticola, and sparsely occurring Gasteruption nigrescens Schletterer, 1885, because all previously published records have not been confirmed. We also provide the descriptions of mature larvae of all three species.

\section{Materials and methods}

The field surveys were done in the winter of 2013-2018 (January to March) in a total of 117 localities in the Czech Republic, Slovakia, Hungary, Poland, Slovenia, and Italy. Most of the localities were sampled only once but several of them repeatedly in two or more years. We collected from 50 to 1000 of over-one-year old galls at each locality. These galls were partly reared in the laboratory in special rearing sacs, the majority of them were longitudinally cut and their contents studied (for more detailed methods and lists of localities, see Bogusch et al. 2015, 2016, 2017, Astapenková et al. 2017). The nest structures, number of brood cells, materials used, pollen and prey contents, and shape of brood chambers were studied and measured, and all larvae were kept until the adults hatched. In the case of presence of Gasteruption larvae in the gall, we studied all remnants of the host's nest (pollen, feces, septa, cocoons) to identify the host to the genus or species level.

We documented the whole larvae using a macro-photographing apparatus consisting of a Canon macro-camera attached to a Nikon stereo microscope with LED illumination. We took photos of living larvae as well as the larvae fixed in Pampel solution (30 volumes of distilled water, 15 volumes of $96 \%$ ethanol, 6 volumes of formaldehyde and 4 volumes of glacial acetic acid) as described by Švácha and Danilevsky (1987). To describe the morphology of larval specimens, we transferred some of the larvae into Pampel solution (while the remaining larvae were allowed to develop to identify the species). After taking photographs of the intact larvae, we examined their sclerotized parts. For this purpose, we placed the larvae into $10 \%$ solution of hot $\left(60{ }^{\circ} \mathrm{C}\right)$ potassium hydroxide for 12 hours to dilute all parts of the body except the integument. Then we coloured the integument in 5\% Chlorazol Black E (Sigma-Aldrich) for 2 seconds and moved the specimens into $96 \%$ ethanol for the conservation. To observe the identification features, we placed the integument into glycerol and separately observed the head, mouthparts, spiracles, and other important parts of the integument under a light microscope. We used the same specimens for the study of small structures such as setae, sensillae, or mouthparts. We drew figures of (1) the head with a focus on the clypeus, labrum, maxillae, and labium; (2) the mandibles from the anterior view; and (3) the spiracles of larvae of each species. 
In order to study the distribution of selected species in the study area, we recorded coordinates of the localities using a standard GPS device. Maps with the spatial distribution of each Gasteruption species and the Hylaeus pectoralis host were created using ArcGIS ver. 10.2 software (ESRI 2012). GPS coordinates were transformed into the GIS layer (pointtype shapefile) and presented in the World Geodetic System 1984 (WGS-84).

\section{Results}

\section{Occurrence of Gasteruption in reed galls}

We recorded three Gasteruption species, of which Gasteruption assectator (G. assectator s. str. according to Johansson and van Achterberg 2016) was the most abundant with 68 individuals recorded at 18 localities in four countries. Equally abundant was Gasteruption phragmiticola with 66 individuals from 24 localities in three countries. Gasteruption nigrescens was recorded in 28 individuals from seven localities in three countries and was the rarest (Table 1).

The occurrence of these three species in reed galls of the studied countries showed an unexpected distribution pattern (see Figure 1 for $G$. assectator and G. nigrescens and Figure 2 for G. phragmiticola and Hylaeus pectoralis). All three species were recorded in the Czech Republic, Slovakia, and Hungary while only G. assectator occurred in Poland and no Gasteruption species were recorded in Italy and Slovenia although we collected Gasteruption larvae in Sečovlje, Slovenia, but it was impossible to identify them to the species level because they did not turn to imagines. Gasteruption phragmiticola was quite common in the Pannoninan part of Slovakia (4 of 6 localities; 67\%) and Hungary $(3 / 8 ; 38 \%)$ while it occurred also in $23 \%$ (17/74) localities in the Czech Republic. It was not recorded north of the Czech Republic in Poland and south of Hungary in Slovenia and Italy. It was relatively abundant at some of the localities (23 individuals in 671 galls from surroundings of Lake Velence near Pákozd in Hungary or 11 individuals in 243 galls from reed bed near Žehuňský fish pond in the Czech Republic) but most commonly it was recorded only by $1-3$ individuals per locality. The localities with high abundance of this species usually consisted of well-preserved large reed beds around big lake or pond nature reserves with rich populations of the host species.

Gasteruption nigrescens was recorded in the same countries but it was very rare in the Czech Republic, where it was only recorded at two localities that were very close to one another and at an additional locality that was about $150 \mathrm{~km}$ south of these localities. It was recorded in two localities both in Hungary and Slovakia, where it was very numerous in the wetland between Virt and Marcelová in Slovakia with 10 individuals in 210 galls (but it is the only locality with more than three individuals recorded). It was recorded mostly in regions with salt marshes and the localities were quite similar to those of $G$. phragmiticola.

Gasteruption assectator s. str. was ubiquitous but occurring at low abundance, with one to several individuals recorded per site (14\% (10) of all localities in the Czech Republic, 16\% (1/6) in Slovakia and 50\% (4/8) in Hungary) and was quite common 
Table I. Numbers of localities of Hylaeus pectoralis, Gasteruption assectator, Gasteruption nigrescens and Gasteruption phragmiticola in countries of the present study. CZ - Czech Republic, SK - Slovakia, SI Slovenia, HU - Hungary, IT - Italy, PL - Poland.

\begin{tabular}{l|c|c|c|c|c|c|c}
\hline \multicolumn{1}{c|}{ Species/Country } & CZ & SK & SI & HU & PL & IT & Total \\
\hline Localities & 74 & 6 & 2 & 15 & 15 & 5 & 117 \\
\hline Hylaeus pectoralis & 35 & 5 & 0 & 8 & 9 & 0 & 57 \\
\hline Gasteruption assectator & 10 & 1 & 0 & 4 & 3 & 0 & 18 \\
\hline Gasteruption nigrescens & 3 & 2 & 0 & 2 & 0 & 0 & 7 \\
\hline Gasteruption phragmiticola & 17 & 4 & 0 & 3 & 0 & 0 & 24 \\
\hline
\end{tabular}

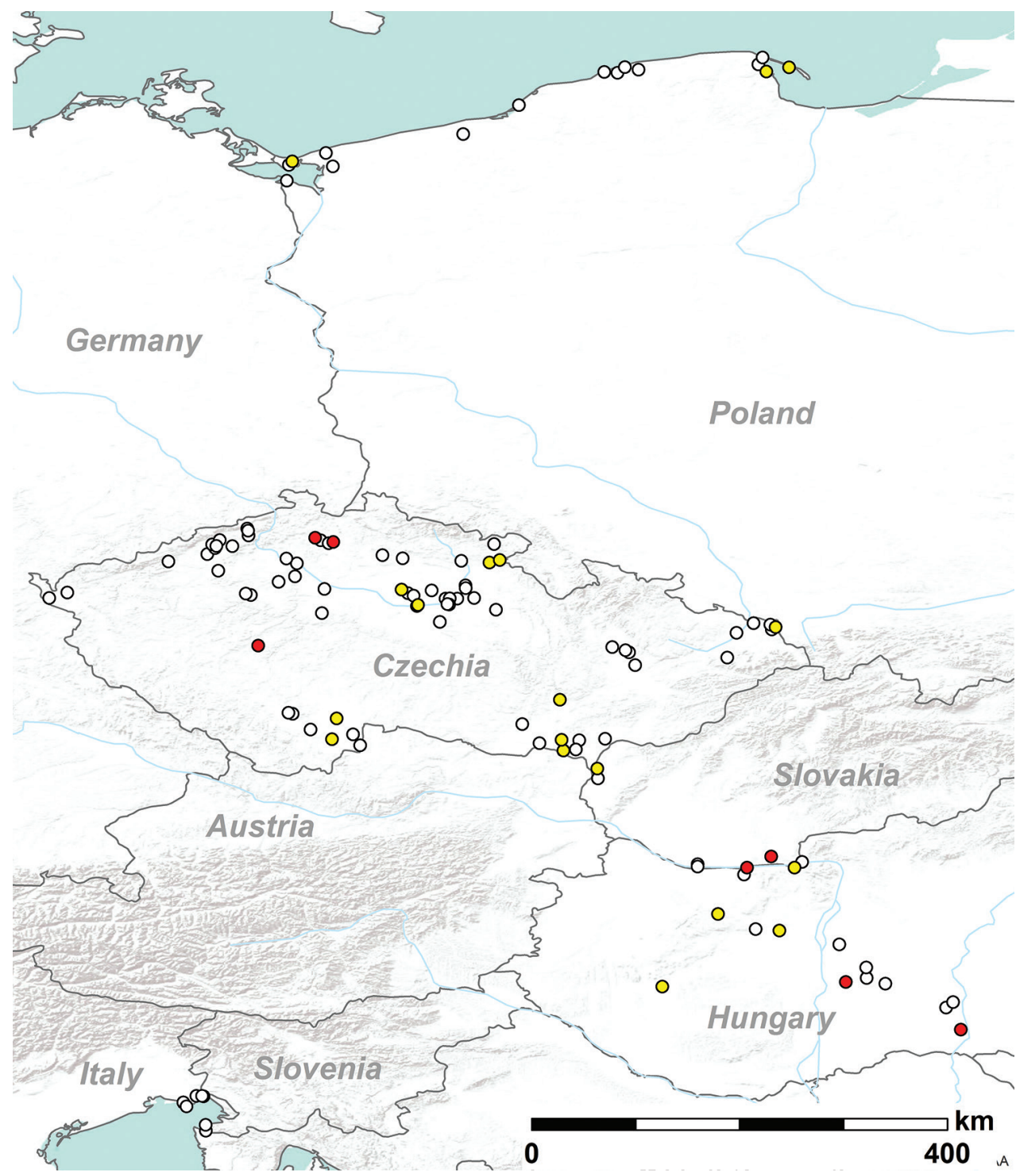

Figure I. Map with occurrence of Gasteruption assectator (yellow) and Gasteruption nigrescens (red) in the localities studied. Empty circles represent the localities where these species have not been recorded. 


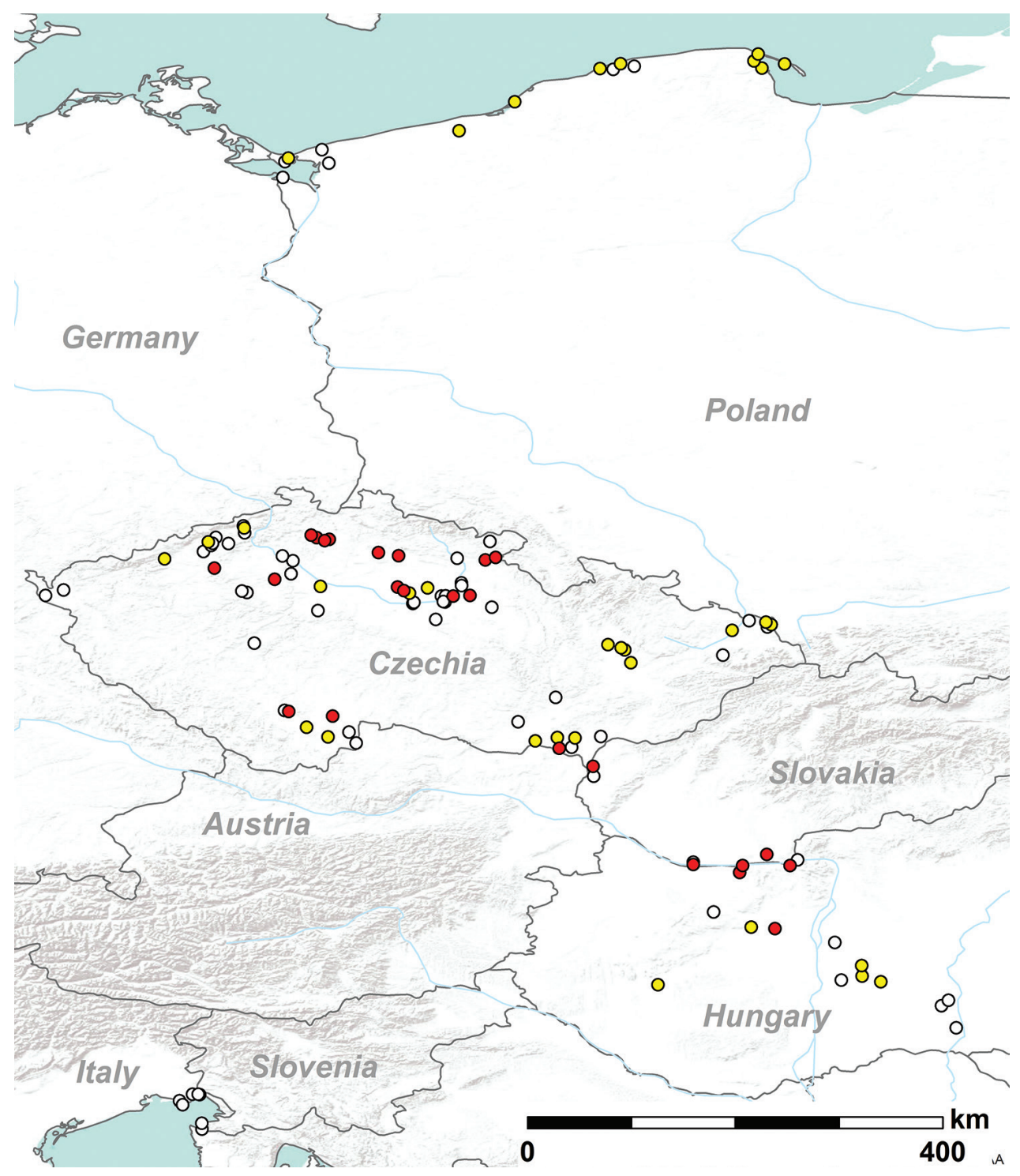

Figure 2. Map with occurrence of Hylaeus pectoralis (yellow) and Gasteruption phragmiticola together with Hylaeus pectoralis (red) in the localities studied. No localities of Gasteruption phragmiticola without the presence of $H$. pectoralis were recorded. Empty circles represent the localities where these species have not been recorded.

also in northern Poland (3/9; 33\% of all localities). Accumulated data suggest that G. assectator is a common species with large distribution range and limited populations at the localities while $G$. phragmiticola has much sparser distribution but forms abundant populations in large reed beds and G. nigrescens is a species occurring only rarely in central Europe. 


\section{Hosts}

In most cases, Gasteruption larvae destroy most of the nest and no host larvae are preserved. Nevertheless, we identified the host in 95 of 162 nests (59\%). G. phragmiticola was parasitizing in nests of the bee Hylaeus pectoralis (51 of 52 G. phragmiticola individuals with identified hosts). We recorded one G. phragmiticola in nests of very numerous Pemphredon fabricii (M. Müller, 1911) but it is likely that the Gasteruption larva was not parasitizing in this species nest but in a neighbouring nest of some bee species. We never recorded this species in nests of the other common potential host species Heriades rubicola Pérez, 1890, and Trypoxylon deceptorium Antropov, 1991. No nest of other species of the genus Hylaeus were parasitized by this species despite they were parasitized by $G$. assectator as specified below (Table 2).

We found that larvae of $G$. nigrescens specialized to parasitize in nests of bees of the family Megachilidae. Larvae of this species were present in nests of common bee Hoplitis leucomelana (Kirby, 1802) and of a small species Heriades rubicola that is recently expanding throughout central Europe. The site with high abundance of $G$. nigrescens (Virt in Slovakia, 10 individuals) was hosted by abundant Heriades rubicola (34 nests in 210 examined galls). However, the abundant presence of $H$. rubicola cannot be considered as the only factor limiting the distribution of $G$. nigrescens as the predation by Gasteruption nigrescens was not recorded or was recorded only in limited numbers at other localities where $H$. rubicola was abundant. There was, for example, only a single parasitized nest in Gbelce, locality about $20 \mathrm{~km}$ near to the locality at Virt, one of five nests of this species in 182 reed galls. We also recorded larvae of this species in a gall with larvae of $P$. fabricii, but it is likely that $G$. nigrescens did not parasitize in the nest of $P$. fabricii but the rest of the gall, where a megachilid species placed its nest.

The last species, $G$. assectator s. str., seems to be the only generalist parasitoid of the three species. It was recorded parasitizing in nests of Hylaeus confusus Nylander, 1852, H. pectoralis and Hoplitis leucomelana and also marginally in nests of the eudominant species nesting in reed galls - the digger wasp Pemphredon fabricii. In the case of the parasitization in $P$. fabricii, remnants of a nest of $P$. fabricii were found in the gall but no remnants of a nest of other species. This can mean not only that $P$. fabricii is a host of $G$. assectator but also that the remnants of the nest of the bee species nesting in the gall were completely destroyed by the Gasteruption larva. Hosts of most of the larvae or adults recorded ( 41 of $68 ; 60 \%$ ) were impossible to identify.

Table 2. Hosts of Gasteruption. Pfab - Pemphredon fabricii, Hpec - Hylaeus pectoralis, Hcon - Hylaeus confusus, Hleu - Hoplitis leucomelana, Hrub - Heriades rubicola.

\begin{tabular}{l|c|c|c|c|c|c|c}
\hline \multicolumn{1}{c|}{ Host species } & Pfab & Hcon & Hpec & Hleu & Hrub & Unknown & Total \\
\hline Gasteruption assectator & 5 & 3 & 17 & 2 & 0 & 41 & 68 \\
\hline Gasteruption nigrescens & 1 & 0 & 0 & 8 & 7 & 12 & 28 \\
\hline Gasteruption phragmiticola & 1 & 0 & 51 & 0 & 0 & 14 & 66 \\
\hline Total & 7 & 3 & 68 & 10 & 7 & 67 & 162 \\
\hline
\end{tabular}




\section{Description of the mature larvae}

Gasteruption larvae in host' nests appear typically in a chamber formed from usually multiple destroyed brood cells (Fig. 3A-C). They differ from host larvae by their dorsoventrally flattened body and lateral lobes on body segments (Figure 4). Although in some cases the larva occupies only a part of the gall and host larvae are also present (Figure 3A), there is usually a single larva in the gall (Fig. 3B, C).

Gasteruption assectator (Linnaeus, 1758), s. str.

Figs 4A-C (whole larva), 5A-C (drawings of body parts)

Previous descriptions. Larva of this common species is mentioned to be the only larva of this genus previously described in literature: Crosskey (1951) published very brief description and Short (1952) described in detail the head of the larva. However, the rest of the body was undescribed, and it is necessary to compile a detailed description of the whole larva.

Material examined. Hungary bor., Tát env., 47.761468, 18.702050, reed bed surrounding water reservoir, 15.i.2016, 1 larva from nest of Pemphredon fabricii, P. Bogusch lgt.; Hungary occ., Balaton region, Fonyód env., 46.738374, 17.586305, terrestrial reed bed, 1 larva from nest of Hylaeus confusus, P. Bogusch \& P. Heneberg lgt., both P. Bogusch det. \& coll.

Diagnosis. The mature larva of $G$. assectator is similar to other larvae of this genus. It is smaller in total length as well as the body parts (head, mandible) are smaller than in the larvae of bigger species $G$. phragmiticola and G. nigrescens. The body is less sclerotized, which is well-visible especially on the head and mouthparts - the yellowish-colored more pigmented mandible, apices of maxillae and labium and antennal tubercles are in contrast with the same parts brownish in the other two species. The mandible is shorter with apical tooth not projecting as much behind the other, its top is blunter than of the other species. The presently described larvae are both very similar in the morphology although they differ in size (which is normal in parasitic species) and their morphology corresponds with the description of Crosskey (1951) and figures of head of G. assectator in Short's (1952) study.

Description. Body: Body length 5.4 and $6.7 \mathrm{~mm}(\mathrm{~N}=2)$. Body vestiture without spicules consisting only of numerous slender, pale setae, tapering to fine points, arising from small but distinct alveoli; these setae conspicuous and elongate. Setae abundant on elevated dorsal surfaces of thorax and widely scattered on anterior ventral surface of thorax; some setae present on dorsal surfaces of metasomal tergites while tergites 3-7 possess less setae than T1-3 and T8-T10. Caudal annulets of abdominal segment 8, 9 , and 10 are most setose; dorsal surface elsewhere with scattered short inconspicuous setae. Body form of postdefecating larva wide and dorsoventrally flattened, robust; body segments of similar width on whole length (Fig. 4A-B). Paired body tubercles absent or very ill-developed on thorax but present and well-developed on metaso- 


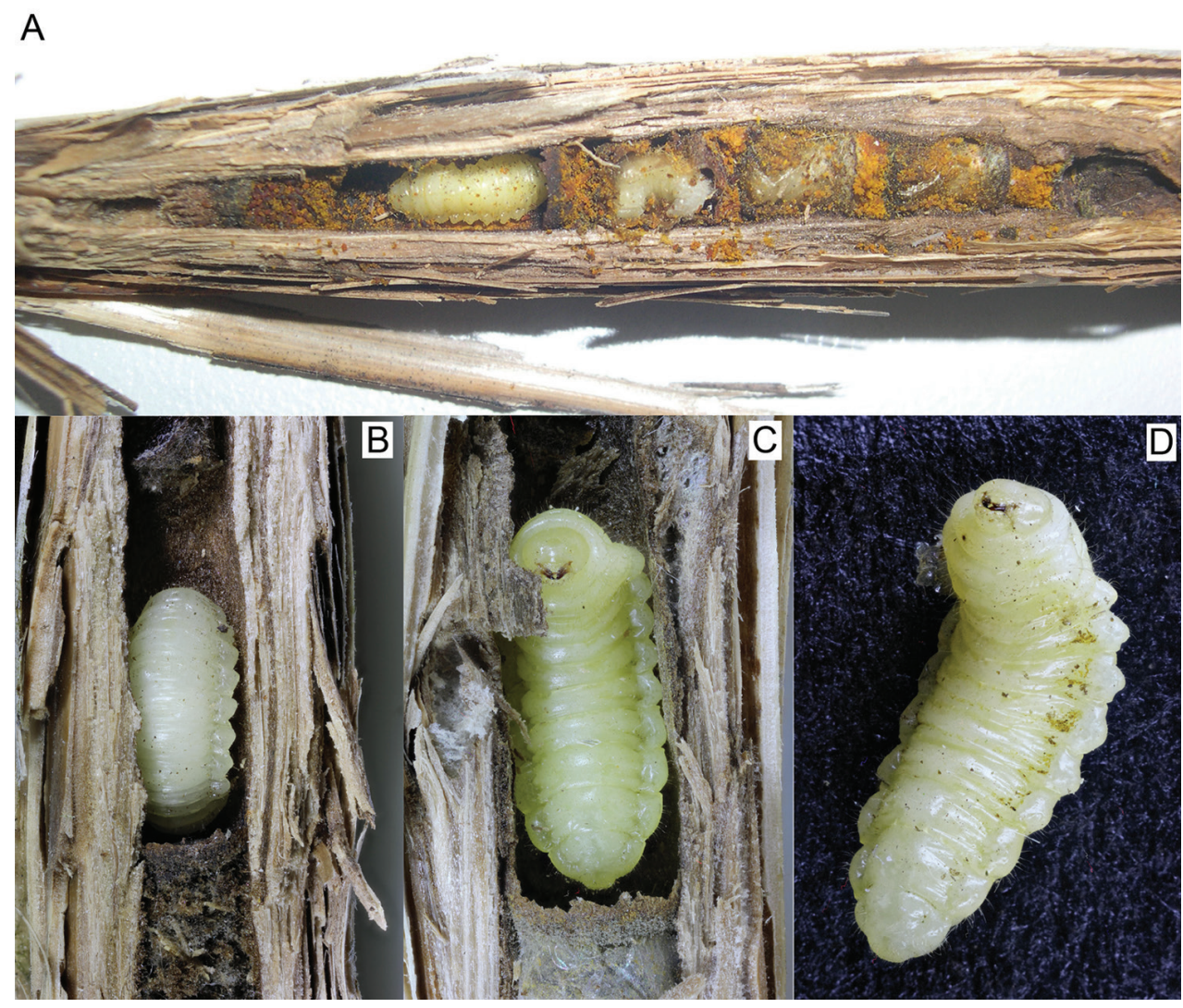

Figure 3. Nests with larvae of Gasteruption. A Larva of Gasteruption nigrescens in nest of Heriades rubicola (Hungary, Szeged, 2017) B Larva of Gasteruption nigrescens in nest of Hoplitis leucomelana (Czech Republic, Novozámecký fish pond, 2018) C Larva of Gasteruption phragmiticola in nest of Hylaeus pectoralis (Czech Republic, Novozámecký fish pond, 2018) D larva of Gasteruption phragmiticola extracted from nest of Hylaeus pectoralis (Czech Republic, Dubno, 2015).

mal segments except last (T10), T7-9 with less-conspicuous tubercles than previous tergites. Dorsal tubercles flat and well-developed on thoracic segments 2 and 3, and abdominal tergites while most conspicuous are on T2-T6. Body shape of predefecating larva in lateral outline with first abdominal segments having greatest diameter and outline tapering slightly forward and strongly backward from there. Abdominal segment 9 shorter and more hirsute than previous, segment 10 attached to middle of segment 9 in lateral view; anus positioned medially and transverse. Spiracles (Figure 5C) unpigmented, subequal in diameter; atrium globular, slightly wider than deep, projecting little above body wall, with rim; atrial opening diameter vs. peritreme width ratio 1.5; atrial inner surface with rows of wrinkles concentric with primary tracheal opening; primary tracheal opening with collar; subatrium long, with about 20 or more chambers of approximately equal size except one or two next to atrium slightly larger in diameter. Sex characters unknown. 
Head: Head moderately small in relation to body size; oriented in normal, hypognathous position relative to thorax. Setae long but sparse on upper part of head capsule; those of maxillary and labial apices large, straight and conspicuous. Head capsule unpigmented except at points of articulations with mandibles; labrum faintly pigmented; mandibles moderately pigmented except mandibular apices and areas of articulation with head capsule strongly pigmented; maxillary sclerites faintly pigmented; salivary lips not projecting, unpigmented; antennal papilla, maxillary and labial palpi all uniformly moderately pigmented (Figs 4C, 5A). Spiculation apparently absent even on hypopharynx, not on maxilla. Coronal ridge present for more than half distance from postoccipital ridge toward level of antennae in frontal view; postoccipital ridge developed but badly visible, not bending forward; hypostomal ridge well developed, giving rise to pronounced dorsal ramus that extends posteriorly for short distance before ending abruptly in front of postoccipital ridge; both hypostomal ridge and ramus unpigmented; posterior part of ridge bending strongly mesad, forming deeply recessed posterior tentorial pit at junction with posterior tentorial bridge; posterior bridge absent in postdefecating larva because specimen preparing to molt; internal pleurostomal ridge obviously present but not well defined; epistomal ridge not developed. Tentorium mostly absent because of impending ecdysis. Parietal bands absent. In lateral view, clypeus not projecting beyond frons, antenna arising from well-developed prominence, and labrum not extending much beyond clypeus. Diameter of basal ring of antenna about two-thirds distance from closest point on ring to center of anterior tentorial pit; antennal papilla distinctly but not strongly pigmented, moderately large and elongate, longer than twice basal diameter, apically rounded, bearing perhaps two sensillae apically. Frontal area between antennae with two linear rows of six setae and one sensilla in middle, two additional setae laterally near highest positioned sensillae. Parietal region with several setae - five setae from pleurostomal ridge to front tentorial pit, four smaller setae under antennal orbit and one conspicuous seta just above basal clypeal margin. Clypeus wide with ill-developed basal and apical margins, two sensillae basally on sides and three small sensillae more medially on each side. Labrum shallowly emarginated apically in middle, with a group of four conspicuous and several smaller sensillae on each side apically; labral sclerite not defined and only very poorly pigmented. Epipharynx simple without any visible structures. Mandible moderately robust, darkly pigmented, tridentate with apical tooth longest and blunt, medial tooth with blunt apex, lateral tooth small; cuspal area developed, projecting, with surface irregularly uneven; outer mandibular surface without setae (Fig 5B). Maxillary apex strongly bent mesad in frontal view, so that maxillary palpus subapical in position; cardo distinct, posterior end directed toward posterior tentorial pit; stipes weakly sclerotized; maxillary palpi elongate, probably more than two times basal diameters, both pigmented like antennal papilla but slightly thinner than papilla. Stipes with four conspicuous setae. Labium not divided into prementum and postmentum; apex moderately narrow in frontal view; premental sclerite apparently absent as well as border between pre- and postmentum. Two setae on both sides and two smaller on ventral surface. Salivary lips round and 


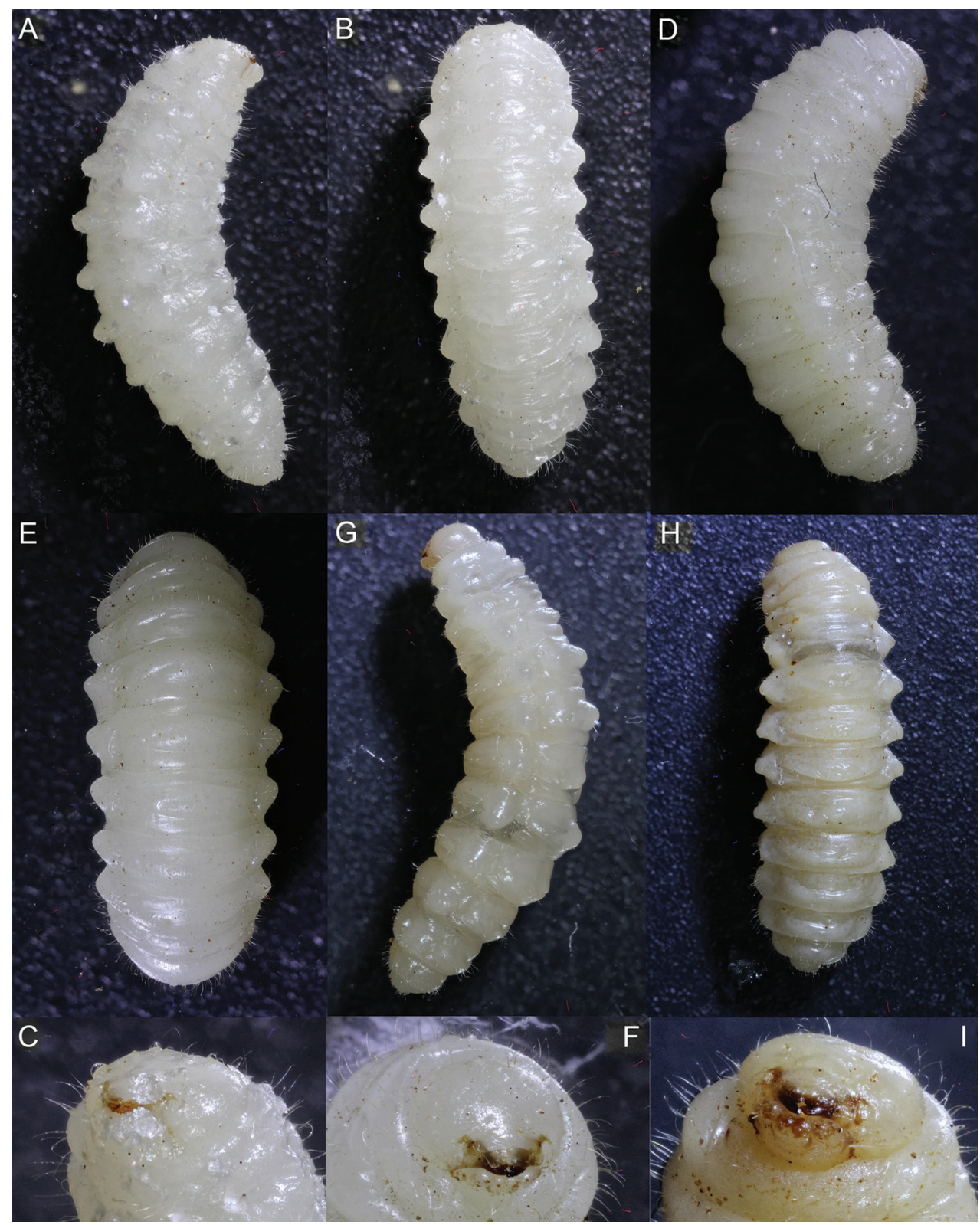

Figure 4. Larvae of Gasteruption. Gasteruption assectator. A mature larva, lateral view B mature larva, dorsal view $\mathbf{C}$ head - mouthparts. Gasteruption nigrescens $\mathbf{D}$ mature larva, lateral view $\mathbf{E}$ mature larva, dorsal view $\mathbf{F}$ head - mouthparts. Gasteruption phragmiticola $\mathbf{G}$ mature larva, lateral view $\mathbf{H}$ mature larva, dorsal view I head - mouthparts.

well-visible, with inner surface bearing parallel longitudinal grooves; width of lips slightly more than double width of maxillary palpus. Labial palpus scale-like with three sensillae in middle. 


\section{Gasteruption nigrescens Schletterer, 1885}

Figs 4D-F (whole larva), 5D-F (drawings of body parts)

Material examined. Czech Republic, Bohemia bor., Jestřebí env., Novozámecký rybník National Nature Reserve, 50.622443, 14.556209, 20.ii.2018, 3 mature larvae from nest of Hoplitis leucomelana, P. Bogusch \& A. Astapenková lgt.; Bohemia bor., Doksy env., Břehyně-Pecopala National Nature Reserve, 50.574244, 14.693014, 20.ii.2018, 1 larva from nest of Hoplitis leucomelana, P. Bogusch \& A. Astapenková lgt.; Hungary centr., Dunatetetlén env., Bödi-Szék salt marsh, 46.772734, 19.144371, 24.ii.2015, 2 mature larvae from nest of Hoplitis leucomelana, P. Bogusch \& P. Heneberg lgt., all larvae P. Bogusch det. and coll.

Diagnosis. The mature larva of $G$. nigrescens is similar to other larvae of this genus, with dorsoventrally flattened body, conspicuous lateral tubercles and tridentate mandibles. It is large, corresponds in size with larva of G. phragmiticola, from which it differs by whitish color in general (larvae of G. phragmiticola are light yellow or creamy yellow in general) and brownish or red-brownish coloration of some setae on the body - especially on the head, mouthparts and last two abdominal segments. The mature larva possesses also more setae on the frons and all the setae on the head are bigger and more conspicuous than those of $G$. phragmiticola. The mandibles are brownish colored and sclerotized, as well as maxillary and labial palpi and end of the labrum - it is in contrast with mature larva of $G$. phragmiticola whose end of labrum is pale yellowish and whole apices of labium and maxilla are brownish pigmented. All studied larvae are very similar in general appearance and do not differ in the chaetotaxy and morphology.

Description. Body: Body length 7.6-9.1 mm $(\mathrm{N}=6)$. Body vestiture without spicules, consisting only of numerous slender, pale setae, tapering to fine points, arising from small but distinct alveoli; these setae conspicuous and elongate. Several setae on mouthparts, vertex and last two abdominal segments brownish colored. Setae moderately abundant on elevated dorsal surfaces of thorax and widely scattered on anterior ventral surface of thorax; some setae present on dorsal surfaces of metasomal tergites while tergites 3-7 possess less setae than T1-3 and T8-T10. Caudal annulets of abdominal segment 7, 8, 9, and 10 are most setose; dorsal surface elsewhere with scattered short inconspicuous setae. Body form of postdefecating larva wide and dorsoventrally flattened, robust; body segments similarly wide on whole length (Figs 4D-E). Paired body tubercles absent or very ill-developed on thorax but present and well-developed on metasomal segments except last (T10), T7-T9 with less conspicuous tubercles than previous tergites. Dorsal tubercles flat and well-developed on thoracic segments 2 and 3, and abdominal tergites while most conspicuous are on T1-T5. Body shape of predefecating larva in lateral outline with first abdominal segments having greatest diameter and outline tapering slightly forward and strongly backward from there. Abdominal segment 9 shorter and more hirsute than previous, segment 10 attached to middle of segment 9 in lateral view; anus positioned medially and transverse. Spiracles (Figure 5F) unpigmented, subequal in diameter; atrium globular, slightly wider than 

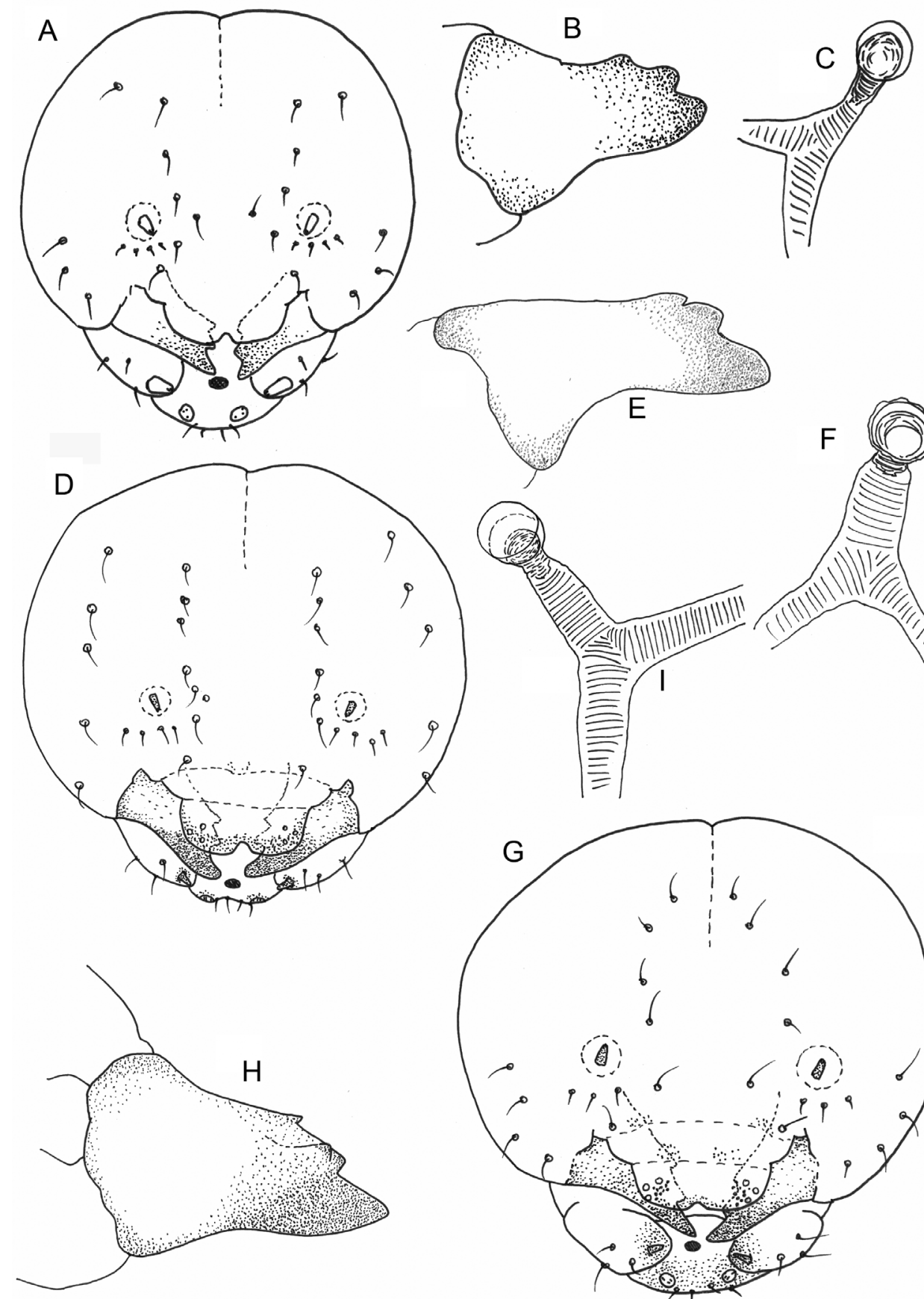
deep, projecting little above body wall, with rim; atrial opening diameter vs. peritreme width ratio 1.5; atrial inner surface with rows of wrinkles concentric with primary tracheal opening; primary tracheal opening with collar; subatrium long, with about 20 or more chambers of approximately equal size except one or two next to atrium slightly larger in diameter. Sex characters unknown.

Head: Head moderately small in relation to body size; oriented in normal, hypognathous position relative to thorax. Setae long but sparse on upper part of head capsule; those of maxillary and labial apices large, straight and conspicuous, several of setae brownish pigmented. Head capsule unpigmented except at points of articulations with mandibles; labrum faintly pigmented except transverse labral sclerite slightly darker; mandibles moderately pigmented except mandibular apices and areas of articulation with head capsule strongly pigmented; maxillary sclerites faintly pigmented; salivary lips not projecting, unpigmented; antennal papilla, maxillary and labial palpi all uniformly moderately pigmented (Figs 4F, 5D). Spiculation apparently absent even on hypopharynx, not on maxilla. Coronal ridge present for more than half distance from postoccipital ridge toward level of antennae in frontal view; postoccipital ridge developed but badly visible, not bending forward; hypostomal ridge well developed, giving rise to pronounced dorsal ramus that extends posteriorly for short distance before ending abruptly in front of postoccipital ridge; both hypostomal ridge and ramus unpigmented; posterior part of ridge bending strongly mesad, forming deeply recessed posterior tentorial pit at junction with posterior tentorial bridge; posterior bridge absent in postdefecating larva because specimen preparing to molt; internal pleurostomal ridge obviously present but not well defined; epistomal ridge not developed. Tentorium mostly absent because of impending ecdysis. Parietal bands absent. In lateral view, clypeus not projecting beyond frons, antenna arising from well-developed prominence, and labrum not extending much beyond clypeus. Diameter of basal ring of antenna about two-thirds distance from closest point on ring to center of anterior tentorial pit; antennal papilla distinctly but not strongly pigmented, moderately large and elongate, longer than twice basal diameter, apically rounded, bearing perhaps two sensilla apically. Frontal area between antennae with two linear rows of six setae and one sensilla in middle, two additional setae laterally near highest positioned sensillae. Parietal region with several setae - five setae from pleurostomal ridge to front tentorial pit, three smaller setae under antennal orbit and one conspicuous seta just above basal clypeal margin. Clypeus wide with ill-developed basal and apical margins, two sensillae basally on sides and three small sensillae more medially on each side. Labrum shallowly emarginated apically in middle, with a group of six conspicuous and several smaller sensillae on each side apically; labral sclerite not defined and only very poorly pigmented. Epipharynx simple without any visible structures. Mandible moderately robust; darkly pigmented, tridentate with apical tooth longest and blunt, medial tooth with blunt apex, lateral tooth small; cuspal area developed, projecting, with surface irregularly uneven; outer mandibular surface without setae (Figure 5E). Maxillary apex strongly bent mesad in frontal view, so that maxillary palpus subapical in position; cardo distinct, posterior end directed toward posterior tentorial pit; stipes 
weakly sclerotized; maxillary palpi elongate, probably more than two times basal diameters, both pigmented like antennal papilla but slightly thinner than papilla. Stipes with four conspicuous setae. Labium not divided into prementum and postmentum; apex moderately narrow in frontal view; premental sclerite apparently absent as well as border between pre- and postmentum. Two setae on both sides and two smaller on ventral surface. Salivary lips round and well-visible, with inner surface bearing parallel longitudinal grooves; width of lips slightly more than double width of maxillary palpus. Labial palpus scale-like with three sensillae in middle.

\section{Gasteruption phragmiticola Saure, 2006}

Figs 3D, 4G-I (whole larva), 5G-I (drawings of body parts)

Material Examined. Czech Republic, Bohemia or., Zlíč env., Dubno Natural Reserve, 50.406146, 16.068075, 05.i.2015, 1 larva from the nest of Hylaeus pectoralis, P. Bogusch, A. Astapenková \& T. Vavřenová lgt.; Czech Republic, Bohemia bor., Jestřebí env., Novozámecký rybník National Natural Reserve, 50.622443, 14.556209, 20.ii.2018, 4 larvae from nests of Hylaeus pectoralis; Bohemia bor., Doksy env., Břehyně-Pecopala National Nature Reserve, 50.574244, 14.693014, 20.ii.2018, 1 larva from nest of Hylaeus pectoralis, P. Bogusch \& A. Astapenková lgt.; Bohemia centr., Žehuň env., Žehuňský rybník National Nature Reserve, 50.151437, 15.304318, 28.i.2017, 2 larvae from nests of Hylaeus pectoralis, P. Bogusch lgt.; Hungary, Pákozd env., Velencei-tó, 20.i.2017, 47.214611, 18.573709, 3 larvae from nests of Hylaeus pectoralis, P. Bogusch lgt., all larvae P. Bogusch det. and coll.

Diagnosis. The mature larva of $G$. phragmiticola is similar to other larvae of this genus, with dorsoventrally flattened body, conspicuous lateral tubercles and tridentate mandibles. It is quite big corresponding with its measures with larva of $G$. nigrescens, of which it differs by creamy or light yellowish color in general (larvae of $G$. nigrescens are white or whitish in general) and all setae on the body pale (larva of G. nigrescens possesses some of the prominent setae on the head, mouthparts, and last two abdominal tergites brownish or red-brownish). The mature larva possesses also less setae on the frons, and all the setae on the head are smaller and less conspicuous than those of $G$. nigrescens (and of similar proportions towards the head as in $G$. assectator). The mandibles are brownish colored and sclerotized, as well apices of labium and maxilla. It is in contrast with mature larva of $G$. nigrescens whose end of labrum is light brownish and brownish pigmented are only mandibles and maxillary and labial palpi. All studied larvae are very similar in general appearance and do not differ in the chaetotaxy and morphology.

Description. Body: Body length 7.3-9.5 mm $(\mathrm{N}=11)$. Body vestiture without spicules, consisting only of numerous slender, pale setae, tapering to fine points, arising from small but distinct alveoli; these setae conspicuous and elongate. Setae moderately abundant on elevated dorsal surfaces of thorax and widely scattered on anterior ventral surface of thorax; some setae present on dorsal surfaces of metasomal tergites 
while tergites 3-7 possess less setae than T1-3 and T8-T10. Caudal annulets of abdominal segment 8,9 , and 10 are most setose; dorsal surface elsewhere with scattered short inconspicuous setae. Body form of postdefecating larva wide and dorsoventrally flattened, robust; body segments similarly wide on whole length (Fig. 4G-H). Paired body tubercles absent or very ill-developed on thorax but present and well-developed on metasomal segments except last (T10), T7-T9 with less conspicuous tubercles than previous tergites. Dorsal tubercles flat and well-developed on thoracic segments 2 and 3, and abdominal tergites while most conspicuous are on T2-T6. Body shape of predefecating larva in lateral outline with first abdominal segments having greatest diameter and outline tapering slightly forward and strongly backward from there. Abdominal segment 9 shorter and more hirsute than previous, segment 10 attached to middle of segment 9 in lateral view; anus positioned medially and transverse. Spiracles (Figure 5I) unpigmented, subequal in diameter; atrium globular, slightly wider than deep, projecting little above body wall, with rim; atrial opening diameter vs. peritreme width ratio 1.5; atrial inner surface with rows of wrinkles concentric with primary tracheal opening; primary tracheal opening with collar; subatrium long, with about 30 or more chambers of approximately equal size except one or two next to atrium slightly larger in diameter. Sex characters unknown.

Head: Head moderately small in relation to body size; oriented in normal, hypognathous position relative to thorax. Setae long but sparse on upper part of head capsule; those of maxillary and labial apices large, straight and conspicuous. Head capsule unpigmented except at points of articulations with mandibles; labrum faintly pigmented except transverse labral sclerite slightly darker; mandibles moderately pigmented except mandibular apices and areas of articulation with head capsule strongly pigmented; maxillary sclerites faintly pigmented; salivary lips not projecting, unpigmented; antennal papilla, maxillary and labial palpi all uniformly moderately pigmented (Figs 4I, 5G). Spiculation apparently absent even on hypopharynx, not on maxilla. Coronal ridge present for more than half distance from postoccipital ridge toward level of antennae in frontal view; postoccipital ridge developed but badly visible, not bending forward; hypostomal ridge well developed, giving rise to pronounced dorsal ramus that extends posteriorly for short distance before ending abruptly in front of postoccipital ridge; both hypostomal ridge and ramus unpigmented; posterior part of ridge bending strongly mesad, forming deeply recessed posterior tentorial pit at junction with posterior tentorial bridge; posterior bridge absent in postdefecating larva because specimen preparing to molt; internal pleurostomal ridge obviously present but not well defined; epistomal ridge not developed. Tentorium mostly absent because of impending ecdysis. Parietal bands absent. In lateral view, clypeus not projecting beyond frons, antenna arising from well-developed prominence, and labrum not extending much beyond clypeus. Diameter of basal ring of antenna about two-thirds distance from closest point on ring to center of anterior tentorial pit; antennal papilla distinctly but not strongly pigmented, moderately large and elongate, longer than twice basal diameter, apically rounded, bearing perhaps two sensilla apically. Frontal area between antennae with two linear rows of four setae and one sensilla ventrally (near clypeus), 
two additional setae laterally near highest positioned sensillae. Parietal region with several setae - six setae from pleurostomal ridge to front tentorial pit, three smaller setae under antennal orbit, and one conspicuous seta just above basal clypeal margin. Same area between these setae with plenty of small sensillae forming rough structure. Clypeus wide with ill-developed basal and apical margins, two sensillae basally on sides and three small sensillae more medially on each side. Labrum deeply emarginated apically in middle, with a group of four conspicuous and many smaller sensillae on each side apically; labral sclerite not defined and only very poorly pigmented. Epipharynx with rough structure only apically. Mandible moderately robust; darkly pigmented, tridentate with apical tooth longest and sharp, medial tooth with blunt apex, lateral tooth small; cuspal area developed, projecting, with surface irregularly uneven; outer mandibular surface without setae (Figure $5 \mathrm{H}$ ). Maxillary apex strongly bent mesad in frontal view, so that maxillary palpus subapical in position; cardo distinct, posterior end directed toward posterior tentorial pit; stipes weakly sclerotized except for conspicuously long stipital rod that is darkly stained by dye, at posterior end articulating with cardo, at anterior end broadening and branching to form weakly pigmented articulating arm of stipes; maxillary palpi elongate, probably more than two times basal diameters, both pigmented like antennal papilla but slightly thinner than papilla. Labium not divided into prementum and postmentum; apex moderately narrow in frontal view; premental sclerite apparently absent as well as border between pre- and postmentum. Two setae on both sides and two smaller on ventral surface. Salivary lips round and well-visible, with inner surface bearing parallel longitudinal grooves; width of lips slightly more than double width of maxillary palpus. Labial palpus scale-like with three sensillae in middle.

\section{Discussion}

The species of the genus Gasteruption are predator-inquilines of solitary bees nesting in various cavities, as well as in reed galls. Although the reed galls produced by frit flies of the genus Lipara have a very thick walls that serve as a defense against predators and parasitoids, three Gasteruption species can predate the larvae of secondary inhabitants of reed galls. Of these species, $G$. phragmiticola is specialized to parasitize in nests of the bee Hylaeus pectoralis, which nests exclusively in reed galls (see Bogusch et al. 2017). Although just Saure (2006) commented that this bee is a likely host of this species and Westrich (2008) stated the same, we provide the first evidence that Hylaeus pectoralis is the host of $G$. phragmiticola. Although another four Gasteruption species have been recorded in connection with $H$. pectoralis by Crosskey (1951), Malyshev (1965), and Westrich (2008), besides $G$. phragmiticola we recorded only $G$. assectator parasitizing in nests of this species. For $G$. assectator, $H$. pectoralis serves only as a satellite host as $G$. assectator is probably a generalist invading nests of various bees. The specialization of the third recorded species, $G$. nigrescens, is still unconfirmed. It is rare and was previously recorded in wetlands at most, although one of its hosts, mason bee Hoplitis leucomelana, 
is a very common species in multiple types of open habitats across central Europe (Westrich 1989, Macek et al. 2010, Falk and Lewington 2015). The association of $G$. nigrescens with H. leucomelana was first described by Schmid-Egger and Saure (2010). In the present study, we recorded G. nigrescens as abundant in nests of Heriades rubicola, a small bee of the same family as $H$. leucomelana. This species is spreading in Europe from south to north and makes its nests especially in reed galls and stalks (Astapenková et al. 2017; Bogusch et al. 2017). As $H$. rubicola belongs to the same family as the previously documented $G$. nigrescens host, $H$. leucomelana, and as $H$. rubicola uses the same nesting resource, the reed galls, it is likely that the use of $H$. rubicola as a host of $G$. nigrescens is a consequence of host switch that occurred only following the recent expansion of $H$. rubicola to the north (Cross and Notton 2017). The combined evidence suggests that some species of the genus Gasteruption are specialists to members of one family, genus or only one species, which contradicts the conclusions of previous studies on the genus Gasteruption (Malyshev 1965, Wall 1994). Recent unpublished findings on the host biology of some other Gasteruption spp. show the same - all specimens reared from nests of bees of the genus Ceratina Latreille, 1802, during years-lasting surveys were only Gasteruption erythrostomum (P. Bogusch, M. Mikát and J. Straka, unpublished records). Also, the records on the hosts of the families Crabronidae and Vespidae published previously by several authors are unlikely - we recorded nests of crabronid species Pemphredon fabricii with larvae of Gasteruption but they were probably not parasitizing larvae of this species. Though it is common that two or more species occupy one reed gall (Bogusch et al. 2015; Astapenková et al. 2017), it is more probable that Gasteruption in these cases parasitized larvae of some bee species in the rest of the nest and destroyed all the nest remnants.

While $G$. assectator is one of the commonest members of the genus across Europe, the other two here studied species were until recent thought to be very rare and recorded in wetlands (Saure 2006, Saure and Schmid-Egger 2010, van Achterberg and Talebi 2014, Bogusch et al. 2017). They are both bound to terrestrial reed beds associated with wet meadows with high diversity of flowering plants, G. nigrescens was recorded in warm sandy regions with high content of salt in soil. The method of collecting galls on common reed is probably the most suitable method when attempting to elucidate the presence/absence of Gasteruption spp. at the chosen locality. Both G. nigrescens and G. phragmiticola are in general not as rare as supposed. The story of the thoughts on their rarity is similar to that of the host of G. phragmiticola. In the Czech Republic, Hylaeus pectoralis was recorded in three sites during the whole $20^{\text {th }}$ century (Bogusch et al. 2007). Our previously published surveys of reed gall aculeate inquilines confirmed $H$. pectoralis occurrence at 35 Czech localities (with new localities still being identified every year), most of which are well-preserved terrestrial reed beds in nature reserves. Using the same method, $H$. pectoralis was also recorded in several reed beds at sites of anthropogenic origin (Heneberg et al. 2014). However, using pan traps (Heneberg et al. 2014) or trap-nests of reed stalk and goldenrod stems (Bogusch et al. 2017) brought only several isolated records of this species. Similarly, G. phragmiticola was not previously recorded from the Czech Republic, Slovakia, and Hungary (Šedivý 1958, 1989) 
while our surveys brought records from many sites in all three countries. Similarly, G. nigrescens was previously reported only from one finding from the Czech Republic (Šedivý 1958, 1989). Combined, the available evidence suggests that two of the three Gasteruption spp. present in reed beds are characteristic species of well-preserved terrestrial reed beds that rarely occur outside these sites and can be best monitored by rearing them from reed galls.

The larvae of the three Gasteruption spp. share a typical body shape. They are quite robust but dorsoventrally flattened, with well-visible lateral lobes of the body. All are hairy, possessing quite many long setae, which are most numerous on last three abdominal segments. Their head is small and hypognathous with tridentate mandibles and only weakly sclerotized mouthparts. They all possess remarkable setae on frons and other parts of the head, and labrum with shallow to deep emargination in the middle. The differences among the three species studied are superficial, mostly in the shape of mandibles, sclerotization and coloration of mouthparts and body setae, and the number of setae on frons. As no detailed descriptions of larvae of this group are known, we can mark this study as the first stone of knowledge of larvae of this enigmatic genus of parasitic wasps.

\section{Acknowledgements}

We would like to thank to all landlords and representatives for getting to the localities. This study was supported by the Specific Research Project of University of Hradec Králové Nr. 2105/2017.

\section{References}

Astapenková A, Heneberg P, Bogusch P (2017) Larvae and Nests of Aculeate Hymenoptera (Hymenoptera: Aculeata) Nesting in Reed Galls Induced by Lipara spp. (Diptera: Chloropidae) with a Review of Species Recorded. Part II. PLoS ONE 12(1): e0169592. https://doi.org/10.1371/journal.pone.0169592

Bogusch P, Straka J, Kment P (2007) Annotated checklist of the Aculeata (Hymenoptera) of the Czech Republic and Slovakia. Komentovaný seznam žahadlových blanokř́́dlých (Hymenoptera: Aculeata) České republiky a Slovenska. Acta Entomologica Musei Nationalis Pragae, Supplementum 11: 1-300.

Bogusch P, Astapenková A, Heneberg P (2015) Larvae and Nests of Six Aculeate Hymenoptera (Hymenoptera: Aculeata) Nesting in Reed Galls Induced by Lipara spp. (Diptera: Chloropidae) with a Review of Species Recorded. PLoS ONE 10(6): e0130802. https://doi.org/10.1371/ journal.pone.0130802

Bogusch P, Macek J, Janšta P, Kubík Š, Řezáč M, Holý K, Malenovský I, Baňař P, Mikát M, Astapenková A, Heneberg P (2016) Post-industrial habitats serve as critical refuges for pioneer species of newly identified arthropod assemblages associated with reed galls. Biodiversity and Conservation 25: 827-863. https://doi.org/10.1007/s10531-016-1070-5 
Bogusch P, Bělastová L, Heneberg P (2017) Limited overlap of the community of bees and wasps (Hymenoptera: Aculeata) nesting in reed galls with those nesting in other cavities. Journal of Insect Conservation 21: 861-871. https://doi.org/10.1007/s10841-017-0025-9

Cross I, Notton DG (2017) Small-Headed Resin Bee, Heriades rubicola, new to Britain (Hymenoptera: Megachilidae). British Journal of Entomology \& Natural History 30: 1-6.

Crosskey RW (1951) The morphology, taxonomy and biology of the British Evanioidea (Hymenoptera). Transactions of the Royal Entomological Society of London 102: 247-301. https://doi.org/10.1111/j.1365-2311.1951.tb00749.x

ESRI (2012) ArcGIS 10.2 Geodatabase Topology Rules. Available online at (http://resources. arcgis.com/en/help/main/10.2/01 mm/pdf/topology_rules_poster.pdf).

Falk S, Lewington R (2015) Field guide to the bees of Great Britain and Ireland. British Wildlife Field Guides. Bloomsbury Publishing, London, 1-336.

Habermehl H (1921) Gezogene parasitische Hymenopteren aus Bayern. Deutsches Entomologisches Zeitschrift 1921: 81-83, 185-186.

Heneberg P, Bogusch P, Astapenková A (2014) Reed galls serve as an underestimated but critically important resource for an assemblage of aculeate hymenopterans. Biological Conservation 172: 146-154. https://doi.org/10.1016/j.biocon.2014.02.037

Jennings JT, Austin AD (2004) Biology and host relationships of aulacid and gasteruptiid wasps (Hymenoptera: Evanioidea): a review. In: Rajmohana K, Sudheer K, Girish Kumar P, Santhosh S (Eds) Perspectives on Biosystematics and Biodiversity. Kerala: University of Calicut, 187-215.

Johansson N, van Achterberg C (2016) Revision of the Palaearctic Gasteruption assectator aggregate, with special reference to Sweden (Hymenoptera, Gasteruptiidae). ZooKeys 615: 73-94. https://doi.org/10.3897/zookeys.615.8857

Kieffer JJ (1912) Evaniidae. Das Tierreich 30: 1-431.

Kula E, Boháč J, Jelínek J (1999) Insect fauna of selected polypore fungi on birch stems in northern Bohemia. Miscellania Zoologica 22: 75-85.

Macek J, Straka J, Bogusch P, Dvořák L, Bezděčka P, Tyrner P (2010) Blanokřridlí České republiky I. Žahadloví. [Hymenoptera of the Czech Republic. I. Aculeata]. Academia, Praha, 1-524. [In Czech]

Malyshev SI (1965) Lebensweise und Instinkte der primitiven Schlupfwespen Gasteruptiidae (Hymenoptera). Zoologische Jahrbücher 92: 239-288.

Oehlke J (1984) Beiträge zur Insektenfauna der DDR: Hymenoptera-Evanioidea, Stephanoidea, Trigonalyoidea. Faunistische Abhandlungen der staatliche Museum für Tierkunde, Dresden 11: 161-190.

Saure C (2006) Gasteruption phragmiticola sp. n., eine neue Gasteruption-Art aus Deutschland (Hymenoptera, Evanioidea, Gasteruptionidae). Beiträge zur Entomologie 56: 125-132.

Schletterer A (1885) Die Hymenopteren-Gattung Gasteruption Latr. (Foenus ant.). Verhandlungen der Zoologish-Botanischen Gesellschaft in Wien 35: 267-326.

Schmid-Egger C, Saure C (2010) Die Schmalbauchwespe Gasteruption nigrescens Schletterer, 1885, neu für Deutschland (Hymenoptera: Gasteruptiidae). Nachrichtenblatt der Bayerischen Entomologen 59: 40-43. 
Short JRT (1952) The morphology of the head of larval Hymenoptera with special reference to the head of the Ichneumonoidea, including a classification of the final instar larvae of the Braconidae. Transactions of the Entomological Society in London 103: 27-66. https://doi.org/10.1111/j.1365-2311.1952.tb02262.x

Steffan-Dewenter I, Leschke K (2003) Effects of habitat management on vegetation and aboveground nesting bees and wasps of orchard meadows in Central Europe. Biodiversity and Conservation 12: 1953-1968. https://doi.org/10.1023/A:1024199513365

Šedivý J (1958) Die tschechoslowakische Arten der Gasteruptioniden (Hym.). Acta Societas Entomologicae Cechosloveniae 55: 34-43.

Šedivý J (1989) Enumeration insectorum Bohemoslovakiae (Check list of Czechoslovak insects) III (Hymenoptera). Acta faunistica entomologica Musei Nationalis Pragae 19: 1-194.

Ševčík J (2003) Insects associated with wood-decaying fungi in the Czech and Slovak republics: a review of present knowledge. Acta Universitas Ostraviensis Faculatits Rerum Naturalium, Biologica-Ecologica 9: 159-165.

Švácha P, Danilevsky ML (1987) Cerambycoid larvae of Europe and Soviet Union. Part I. Acta Universitatis Carolinae Biologica 30: 1-176.

van Achterberg C, Talebi AA (2014) Review of Gasteruption Latreille (Hymenoptera, Gasteruptiidae) from Iran and Turkey, with the description of 15 new species. ZooKeys 458: 1-187. https://doi.org/10.3897/zookeys.458.8531

Westrich P (1989) Die Wildbienen Baden-Württembergs. Band 1 und 2. Eugen Ulmer Verlag, Stuttgart, 1-972.

Westrich P (2008) Zur Überflutungstoleranz von Hymenopteren in Gallen von Lipara lucens (Diptera: Chloropidae). Eucera 1: 1-16.

Wall I (1994) Seltene Hymenopteren aus Mittel-, West- und Südeuropa (Hymenoptera Apocrita: Stephanoidea, Evanioidea, Trigonalyoidea). Entomofauna 15(14): 137-184. 